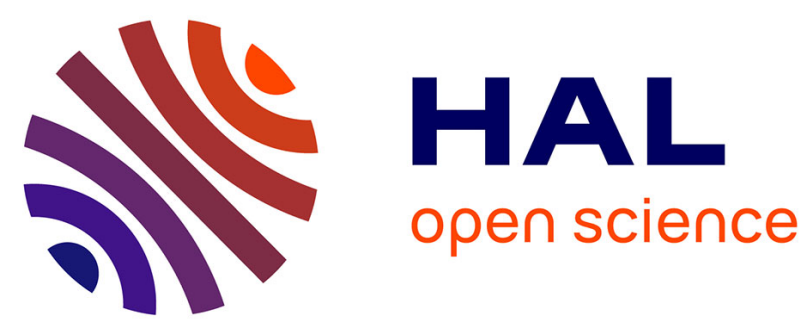

\title{
Is it acceptable for a psychiatrist to break confidentiality to prevent spousal violence?
}

Myriam Guedj, Maria Teresa Muñoz Sastre, Etienne Mullet, Paul Clay Sorum

\section{To cite this version:}

Myriam Guedj, Maria Teresa Muñoz Sastre, Etienne Mullet, Paul Clay Sorum. Is it acceptable for a psychiatrist to break confidentiality to prevent spousal violence?. International Journal of Law and Psychiatry, 2009, 32 (2), pp.108-114. 10.1016/j.ijlp.2009.01.003 . hal-01953031

\section{HAL Id: hal-01953031 \\ https://hal-univ-tlse2.archives-ouvertes.fr/hal-01953031}

Submitted on 6 Jul 2021

HAL is a multi-disciplinary open access archive for the deposit and dissemination of scientific research documents, whether they are published or not. The documents may come from teaching and research institutions in France or abroad, or from public or private research centers.
L'archive ouverte pluridisciplinaire HAL, est destinée au dépôt et à la diffusion de documents scientifiques de niveau recherche, publiés ou non, émanant des établissements d'enseignement et de recherche français ou étrangers, des laboratoires publics ou privés. 


\title{
Is it acceptable for a psychiatrist to break confidentiality to prevent spousal violence?
}

\author{
Myriam Guedj ${ }^{\text {a }}$, Maria Teresa Muñoz Sastre ${ }^{\text {a }}$, Etienne Mullet ${ }^{\mathrm{b}}$, Paul Clay Sorum ${ }^{\mathrm{c}, *}$ \\ a Université du Mirail, Toulouse, France \\ ${ }^{\mathrm{b}}$ Ecole Pratique des Hautes Etudes, Paris, France \\ c Albany Medical College, Albany, New York, USA
}

\section{A R T I C L E I N F O}

\section{Keywords:}

Patient confidentiality

Psychiatrist

Patient-physician relationship

Spousal abuse

France

Public opinion

\begin{abstract}
A B S T R A C T
Study question: When is it acceptable for a psychiatrist to break confidentiality to protect the wife of a potentially violent patient?

Methods: 153 lay persons, 13 nursing personnel, 10 physicians, and 10 psychologists in France indicated this acceptability in 48 scenarios. The scenarios were all combinations of 5 factors: gravity of threat (death or beating), certainty of mental illness (certain or not), time spent talking with patient (considerable or little), his attitude toward psychotherapy (rejection, indecision, or acceptance), and whether the physician consulted an expert. Results: Lay people favored breaking confidentiality more than did nursing personnel or psychologists. Consulting an expert had greatest impact. Lay participants were composed of groups that found breaking confidentiality "always acceptable" (22 participants), "depending on many circumstances" (106), requiring "consultation with an expert" (31), and "never acceptable" (27).

Conclusion: Lay people in France are influenced by situational factors when deciding if a psychiatrist should break confidentiality to protect a patient's wife.
\end{abstract}

\section{Introduction}

Confidentiality is essential for good psychiatric therapy. It is necessary for the establishment of trust between psychiatrists and patients. Without such trust, patients may not disclose all pertinent information, especially about irrational thoughts, inappropriate emotions, and abnormal behaviors. Without complete disclosure, psychiatrists may not be able to make accurate diagnoses, undertake effective treatments, and arrange for appropriate follow-up. Moreover, trust is needed to achieve patient-psychiatrist relationships that may themselves be therapeutic. Revealing medical secrets would risk alienating patients in need of care (Hoerni \& Benezech, 1996). The importance of confidentiality is, therefore, recognized in codes of medical conduct from Hippocrates to the present.

Confidentiality has, however, its limits. When psychiatrists suspect that their patients' behaviors will put other persons at risk, they must decide whether to maintain confidentiality or to break it in order to try to protect the other persons (whether by warning them directly or by alerting the authorities). On this issue, the laws, judicial rulings, and codes of medical ethics differ between the United States and the United Kingdom, on the one hand, and France, on the other.

\footnotetext{
* Corresponding author. Latham Med-Ped, 724 Watervliet-Shaker Road, Latham, NY 12110, USA. Tel.: +1 518262 7500; fax: +1 5182627505 .

E-mail address: sorump@mail.amc.edu (P.C. Sorum).
}

\subsection{Breaking confidentiality in the US, the UK, and France}

In the United States and the United Kingdom, it is considered legitimate to break confidentiality in some situations in order to protect other persons. The Supreme Court of California asserted in the Tarasoff case in 1974 and again in 1976 that, once a psychiatrist determines that his or her patient intends to murder or commit serious harm to an identifiable person, the psychiatrist has a duty to take reasonable measures to inform or protect the intended victim (Felthous, 1999). The "Tarasoff mandate" has been reaffirmed in judicial rulings in most states (Offit et al., 2004; Regan et al., 2002; in contrast, Scarano et al., 2002). The American Medical Association's Code of Medical Ethics (section E-5.05, last updated in 1994) states: "The obligation to safeguard patient confidences is subject to certain exceptions which are ethically and legally justified because of overriding social considerations. Where a patient threatens to inflict serious bodily harm to another person or to him or herself and there is a reasonable probability that the patient may carry out the threat, the physician should take reasonable precautions for the protection of the intended victim, including notification of law enforcement authorities" (AMA, 1994). British physicians have received this same ethical directive from the General Medical Council (GMC, 2004) and the British Medical Association (BMA, 1999).

In France, in contrast, the emphasis in law and medical ethics is more on preserving patient confidentiality. In the Penal Code (Code pénal), Article 226-13 states: "The revelation of confidential information (information à caractère secret) by a person who possesses it 
either by profession or by reason of a function or of a temporary mission is punished by one year of prison and a fine of 15,000 euros." Article 226-14 does add an exception, the obligation to report to the police chief if the clinician knows that the patient has a firearm or intends to purchase one (since private ownership of a gun is against the law in France). In addition, Article 223-6 states that "whoever is able to prevent by immediate action, without risk for him or a third person, either a crime or an offense against a person's bodily integrity but abstains voluntarily to do it is punished by 5 years of prison and 75,000 euros." Nonetheless, Article L1110-4 of the Public Health Code reasserts both the principle and penalty of Article 223-13 of the Penal Code (Code de santé publique; see also Memeteau, 1995). Moreover, the Ordre des Médecins, the body responsible for maintaining the ethical and professional integrity of French physicians, states in Article 4 of the Code of Medical Ethics (as revised in 1995): "Professional confidentiality (le secret professionnel), instituted in patients' interest, is obligatory for every physician within the conditions established by law. Confidentiality applies to everything the physician learns in the exercise of his profession; that is to say, not only what has been confided to him, but also what he has seen, heard or understood." (CNOM, 1996). No exception is made to protect other people.

\subsection{Domestic violence}

The issue of patient confidentiality becomes emotionally very charged when it concerns possible violence to a patient's spouse or intimate partner and, even more, when this violence is likely to result in her death. The issue of confidentiality merges with the increasing concern, in medical circles as well as among the public, about partner abuse and violence. Partner abuse can be defined as any behavior within an intimate relationship that causes physical, psychological, or sexual suffering or injury to one or both of the partners.

Although violence of women towards men exists, spousal or partner violence is essentially exerted by men on women. About one woman in five in the Western world is subjected to domestic violence at some point in her life (de Vries Robbe et al., 1996; Roberts et al., 1998). The percentage of women assaulted by a partner in the twelve previous months varied from 3\% in Australia (Mazza et al., 2000) to 9\% in France (Jaspard and ENVEFF, 2001) to 12\% in the United States (Rodriguez et al., 2001). Such violence results in a considerable number of deaths. Studies conducted in Australia, Canada, Israel, South Africa and the United States show that from 38\% to 70\% of murdered women were killed by their husbands or their boy friends (Bailey, 1999; Daly \& Wilson, 1994; Mouzos, 1999).

We chose to study this especially problematic issue of whether to break confidentiality when the patient's wife is at risk of being murdered by her mentally ill husband.

\subsection{Attitudes toward breaking confidentiality}

In the United States, mental health professionals' assessments of the acceptability of breaking confidentiality about HIV infection tend to follow the "Tarasoff mandate" (Chenneville, 2000; Erickson,1990, 1993; Hook \& Cleveland, 1999; McGuire et al., 1995; Stewart \& Reppuci, 1994; Totten et al., 1990). In contrast, in France, although mental health professionals have not been surveyed, Moatti et al. (1995) found that, in accord with the Ordre des Médecins, general practitioners were in favor of maintaining confidentiality about HIV infection when patients had not consented to having their medical information revealed, except when the information was to be communicated to another health care professional.

The attitudes of lay people in the United States, the United Kingdom, and France have been studied even less (Rubanowitz, 1987). In the United Kingdom, Jones (2003) found considerable support in a small sample of 30 consecutive patients for breaking confidentiality to protect third parties. In France, Guedj, Muñoz Sastre, Mullet, and
Sorum (2006) found, in their study of 144 lay people, 10 psychologists, and 7 physicians, that lay people and psychologists were much more approving than were physicians of a physician breaking confidentiality to protect the wife of patient with a sexually transmitted disease. The patient's stated intentions to protect his spouse and to inform her of the disease had greater impacts on acceptability than did the severity of the disease, the time taken by the physician to discuss the issue with the patient, or the physician's decision whether or not to consult an expert. A cluster analysis revealed groups of lay participants that found breaking confidentiality "always acceptable", "depending on the many circumstances" (the large majority), requiring "consultation with an expert", and "never acceptable."

The results of these studies and the statements of medical bodies have identified several factors that are likely to have important influences on the attitudes of lay participants, psychiatrists, and other health professionals about breaking confidentiality in the case of possible domestic violence: (a) the level of danger to the other person (in this case, his wife); (b) the state of the patient's mental health; (c) the time taken by the doctor to discuss the issue with the patient; (d) the patient's attitude as regards appropriate psychiatric treatment, and (e) the advice received from another, more expert doctor. We examined-in the specific context of a husband found by his psychiatrist potentially to be violent towards his wife-the relative impact of these five factors on lay people's judgments of the acceptability of breaking confidentiality, the possible interactions among these factors, and the impact on participants' judgments of their socio-demographic characteristics (age, gender, religiosity, and educational level). We then compared the acceptability judgments of lay persons with those of health professionals (nursing personnel, medical doctors, and psychologists).

This study was not an epidemiological study; i.e., we were not interested in assessing precisely how many people find a psychiatrist's particular decision acceptable or unacceptable. For such a study, a large, representative sample of subjects would have been needed. This study was a cognitive study; i.e., we were interested in the mental processes by which an individual judges the acceptability of a psychiatrist's decision by integrating the information that constitutes the basis of this decision. For such a study, a limited sample of participants is sufficient because the repertoire of cognitive processes is limited (Anderson, 1996) (as demonstrated by the study by Guedj et al. (2006) described above).

\section{Methods}

The methodology was an application of the Functional Theory of Cognition of Norman Anderson (Anderson, 1981, 1982, 1996). The primary aim of Anderson's methodology is to reveal the cognitive rules used by people to integrate information when they make a judgment or decision. It assumes that people place subjective values on different pieces of information and that they combine these subjective values by means of a cognitive algebra dominated by addition, multiplication, and averaging. It studies how they do this indirectly and functionally, i.e. it infers from people's judgments of the combined value of two or more stimuli (or pieces of information) the cognitive rules used to arrive at these judgments.

In Anderson's methodology, participants evaluate combinations of factors, rather than single factors. Accordingly, we presented our participants with a series of patient vignettes rather than with a questionnaire and thereby were able to simulate the way the issue would appear in real life-in the context of concrete patients with particular characteristics. Anderson's methodology requires, in addition, a complete factorial design, i.e., our set of vignettes had to consist of all possible combinations of the within-subjects factors. This design not only facilitates the determination of the impact of each factor on the overall judgments, but is necessary for the investigation of their interactions and of the cognitive rules participants have used in 

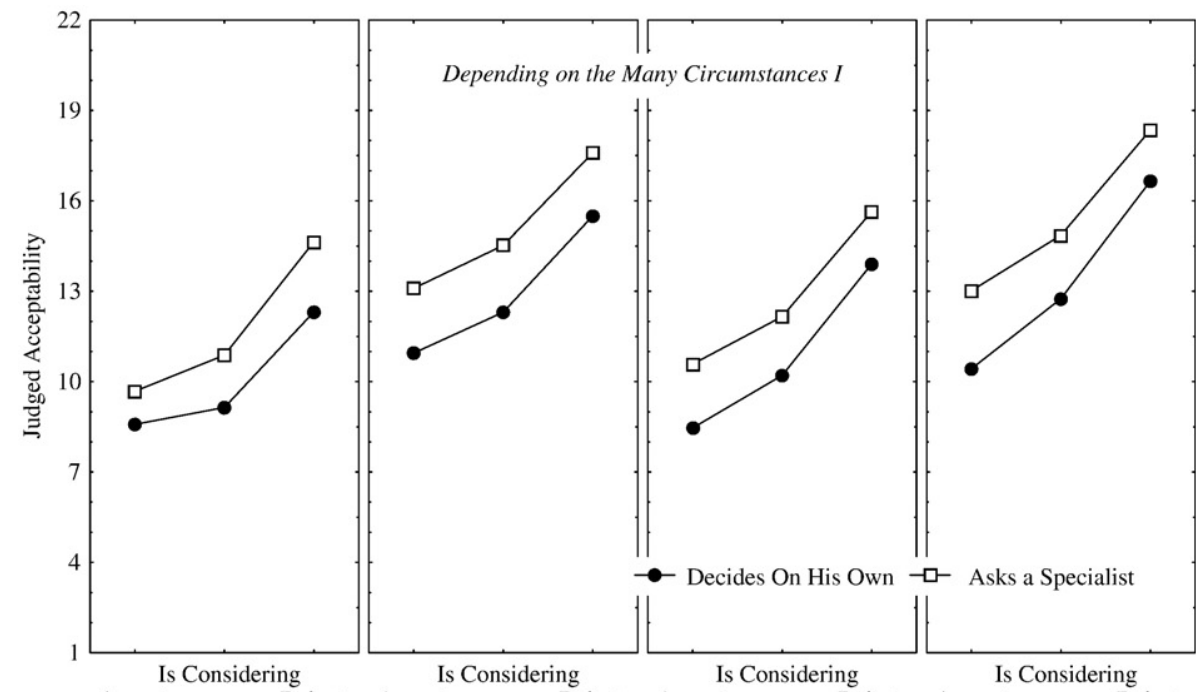
Accepts Rejects Accepts

Brief Time \& Not Certain Brief Time \& No Doubt Consid. Time \& Not Cert. Consid. Time \& No Doubt
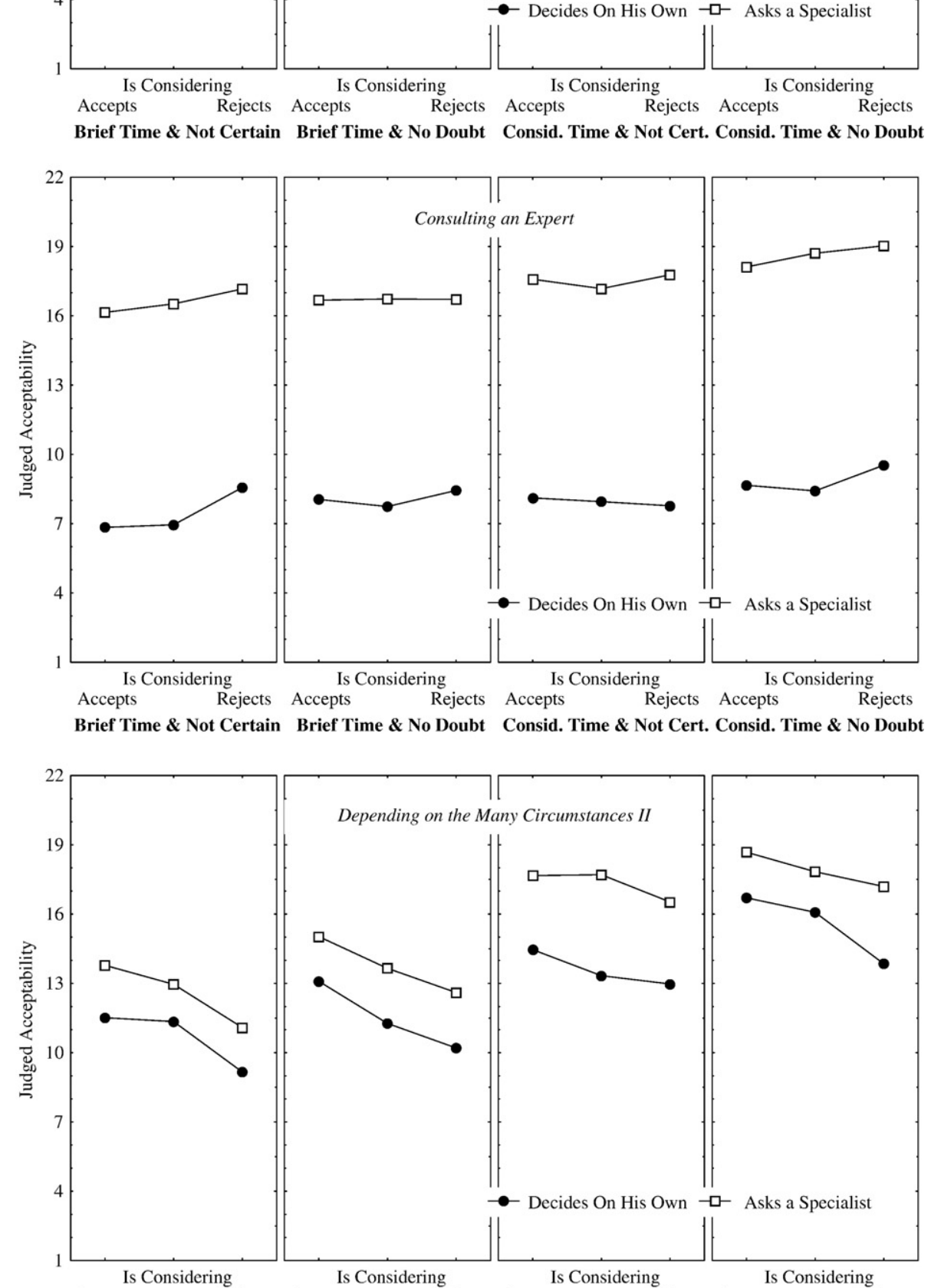

Is Considering

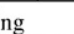

Acepts

Rejects

Brief Time \& Not Certain Brief Time \& No Doubt Consid. Time \& Not Cert. Consid. Time \& No Doubt 
combining them. Furthermore, Anderson found that the true importance for people of each factor and the cognitive rules they employed were revealed better by stable rather than by momentary judgments of combined values. His methodology also requires, therefore, that participants become familiar with the task and with these combinations of variables in a "familiarization" phase before they give a final set of judgments.

\subsection{Participants}

The lay participants were unpaid volunteers recruited and tested by one of the authors (MG). She contacted 250 people walking along sidewalks on the university campus and in the city of Toulouse, explained the study, asked them to participate, and, if they agreed, arranged where and when to administer the experiment. Of these, 153 (61\%) participated. She also contacted 20 nursing personnel, 20 medical doctors, and 20 psychologists working in private offices or in the main hospitals of Toulouse. Of these, 33 (55\%) participated: 13 nursing personnel, 10 medical doctors, and 10 psychologists.

\subsection{Material}

The material consisted of 48 cards containing a story of a few lines, a question, and a response scale. The vignettes were composed according to a five within-subject factor design: (1) the gravity of the threat (to kill his wife or to beat her severely) $\times(2)$ the certainty of mental illness (the diagnosis is not in doubt or is not at all certain) $\times(3)$ the time taken to discuss the consequences of the threatened action (considerable or brief) $\times(4)$ the patient's attitude toward undergoing psychotherapy (refuses it, is considering it, or immediately agrees to it) $\times(5)$ the decision to consult a medico-legal expert (asks a specialist or decides on his own), $2 \times 2 \times 2 \times 3 \times 2$. Other information was held constant: notably, all patients were males, and in each case the doctor decided to call personally the patient's wife in order to inform her that her husband was potentially very dangerous.

Under each vignette were a question-“To what extent do you think that the decision made by [the psychiatrist] is acceptable?"-and a 22-cm linear response scale with anchors of "Not at all acceptable" and "Completely acceptable." Two examples are given in the Appendix. The cards were arranged by chance and in a different order for each participant.

Finally, the participants answered additional questions about age, gender, educational level, religious belief, and religious background.

\subsection{Procedure}

The site was, for the lay people, either a vacant university classroom or the participant's private home, and for the professionals, their office or a vacant hospital room. Each person was tested individually. The session had two phases. In the familiarization phase, after the experimenter explained what was expected, the participant read each vignette out loud, was reminded by the experimenter of the items of information in it, and indicated on the response scale the acceptability of breaking confidentiality. After completing the 48 ratings, the participant was allowed to look back at, compare, and change his or her responses. In the experimental phase, the participant again looked at each vignette, but worked at his or her own pace and was not allowed to look back at and change previous responses. In both phases, the experimenter made certain that each subject, regardless of age, educational level, or professional status, was able to understand all the necessary information before making a rating.

Both the lay people and the professionals took 30-45 min to complete both phases. The experimental phase went quickly because they were already familiar with the task and the material. No lay person or professional complained about the number of vignettes or about their credibility.

\subsection{Data analysis}

For each of the 48 scenarios in the experimental phase, the distance was measured between the left anchor and each answer given by the participant on the response scale. All subsequent analyses were based on these measures.

In accordance with Anderson's methodology, the data were analyzed, at the group level (lay people, nursing personnel, medical doctors, and psychologists), by performing analyses of variance (ANOVAs) and by constructing graphs (using Statistica 5.0). As regards the lay persons sample, the design of the ANOVA was participant's Age $\times$ Gender $\times$ Severity of risk $\times$ Mental state $\times$ Time taken $\times$ Attitude toward treatment $\times$ Expert, $2 \times 2 \times 2 \times 2 \times 2 \times 3 \times 2$. Educational level was not introduced as a factor in this design because preliminary analyses showed that it had no significant effect and was not involved in significant interactions with the other factors. As regards the other samples, the design of the ANOVA was reduced to Severity of risk $\times$ Mental state $\times$ Time taken $\times$ Attitude toward treatment $\times$ Expert, $2 \times 2 \times 2 \times 3 \times 2$. In addition, an ANOVA was conducted with Professional (yes or no) as an inter-group factor and with the five intra-group factors, $2 \times 2 \times 2 \times 2 \times 3 \times 2$.

A cluster analysis was also conducted on the combined raw data from all the participants.

\section{Results}

\subsection{Characteristics of participants}

The lay participants consisted of 153 persons ( 108 females and 45 males) aged 18-79 years, with a mean age of 30 years 4 months. Eighty-six percent had completed secondary education. All but four reported that they were in good health. Forty percent were religious believers and $60 \%$ non-believers, although only $5 \%$ were churchgoers.

The 13 nursing personnel (12 females and 1 male) were aged 2555 years, with a mean of 34 years 7 months. The 10 medical doctors ( 5 females and 5 males) were aged 27-58, with a mean of 44 years 3 months. Eight were primary care doctors and two were specialists working in a hospital. The 10 psychologists ( 8 females and 2 males) were aged $25-36$ years, with a mean of 20 years.

\subsection{Lay participants}

For the lay participants, the overall mean value of all the ratings was $12.97 \mathrm{~cm}$. The highest mean response, $17.79 \mathrm{~cm}$, was still very distant from the possible maximal answer, $22 \mathrm{~cm}$. There was thus no ceiling effect to complicate the interpretation of the results.

Each of the five within-subjects factors under study had a significant effect. The less the patient was willing to accept an appropriate therapy, the more acceptable the decision $(14.07-12.22=1.85), F(2,298)=21.11$, $p<.001$, Cohen's $d=.28$. If an expert was consulted, the decision was judged more acceptable than if an expert was not consulted (14.59$11.36=3.23), F(1,149)=92.35, p<.001, d=.49$. The more time the psychiatrist has taken for discussing with the patient, the more 
Table 1

Composition of the clusters as a function of the participants' sample

\begin{tabular}{lllllr}
\hline Cluster & $\begin{array}{l}\text { Lay } \\
\text { participants }\end{array}$ & $\begin{array}{l}\text { Nursing } \\
\text { personnel }\end{array}$ & Psychologists & $\begin{array}{l}\text { Medical } \\
\text { doctors }\end{array}$ & Total \\
\hline Always Acceptable & 19 & 1 & 0 & 2 & 22 \\
Depending on Circumstances I & 61 & 3 & 3 & 0 & 67 \\
Consulting an Expert & 25 & 1 & 1 & 4 & 31 \\
Depending on Circumstances II & 34 & 3 & 1 & 1 & 39 \\
Never Acceptable & 14 & 5 & 5 & 3 & 27 \\
Total & 153 & 13 & 10 & 10 & 186 \\
\hline
\end{tabular}

acceptable the decision $(13.69-12.26=1.43), F(1,149)=34.07, p<.001$, $d=.22$. The more evident the patient is suffering from mental illness, the more acceptable the decision $(13.85-12.10=1.75), F(1,149)=93.79$, $p<.001, d=.27$. Finally, the more severe the threat, the more acceptable the decision $(13.35-12.60=0.75), F(1,149)=16.71, p<.001, d=.12$. None of the two between-subjects factors (age and gender) had a significant effect.

Only one significant interaction was observed. It involved Age and Mental Illness, $F(1,149)=17.91, p<.001$. Mental illness had more impact on acceptability among younger participants (14.19$11.68=2.51)$ than among older participants $(13.50-12.52=0.98)$.

\subsection{Health professionals}

Health professionals as a whole were less favorable to breaking confidentiality than were lay people, with a mean acceptability rating of 10.47 versus $12.97, F(1,185)=6.62, p<.01$.

The pattern of ratings of the nursing personnel was similar to that of the lay participants. Four of the five main effects were significant (the Attitude toward treatment factor was not significant). The mean acceptability value was lower (9.83) than that for the lay people (12.97), $p<.05$.

The pattern of ratings of the psychologists was also similar to the lay participants'. All five main effects were present. The mean acceptability value was also lower (7.97) than that for the lay people, $p<.005$.

The pattern of ratings of the medical doctors was different from the other three patterns. Only three effects were present: Consulting an expert, Mental illness, and Severity of the threat. The mean acceptability value (13.09) was almost identical to that of the lay people.

\subsection{Cluster analyses}

The cluster analysis revealed five very different clusters (see Fig. 1). The first cluster $(N=22$, not shown), named Always acceptable, had a mean acceptability rating of 20.34, i.e., close to the maximum value of 22 . None of the five factors had a significant effect. The second cluster $(N=67)$, named Depending on the Many Circumstances I, had a mean acceptability rating of 12.80 , i.e., slightly higher than the mid-point of the scale. All five factors had significant effects. In addition the Attitude toward therapy $\times$ Time taken to discuss interaction was significant in this cluster: the less positive the attitude, the greater the impact of the Time taken factor. The third cluster $(N=39)$, Depending on the Many Circumstances II, showed the same properties as the previous cluster, except that the direction of the effect of the Attitude toward treatment factor was reversed: The more positive the attitude, the more acceptable the decision. Also the mean level of acceptance was higher: 13.89. The fourth cluster $(N=31)$, labeled Consulting an Expert, had a mean acceptability rating of 12.32 , i.e., also slightly higher than the midpoint of the scale; but consultation with an expert in spousal violence among psychiatric patients was the only factor to have a significant effect. The fifth cluster $(N=27)$, called Never acceptable (not shown), had a mean acceptability rating of 2.86 , i.e., close to the minimum value of 1 . Again none of the five factors had a significant effect.
Table 1 shows the composition of the Clusters as a function of the participants' professional identity. Among the lay persons, $62 \%$ took into account the many circumstances before judging and an additional 16\% took into account at least one circumstance (consulting an expert). Among the health professionals and among the psychologists, 35\% took into account several circumstances, and an additional $9 \%$ took into account at least one circumstance. Among the medical doctors, just one of them took into account the many circumstances. The other doctors were either always or never in agreement with the decision or just took into account the consultation of an expert.

\section{Discussion}

When a psychiatrist learns that her or his patient is potentially dangerous for his spouse, the psychiatrist must make a difficult decision: whether to maintain strict confidentiality and thereby put the partner at risk or to inform the partner and thereby violate the ethic of confidentiality. Our study of the acceptability among French people of breaking confidentiality in such situations provided some striking results.

Our first major finding was that, for the majority of lay people, all of the five factors we studied had direct effects on the acceptability of breaking confidentiality. In order of importance, these were 1) the psychiatrist's consultation with an expert prior to the decision, 2) the patient's attitude toward appropriate psychotherapy, 3) the certainty of mental illness, 4) the time taken to talk with the patient, and 5) the gravity of the threat. Overall, these results were consistent with the findings by Guedj et al. (2006). In the present study, however, lay participants attributed more importance to consultation with an expert and less importance to the patient's intentions than in the study by Guedj et al. (2006).

People were well aware that, even when the threat could eventually result in death, such decisions are not clear-cut, are fraught with moral complexity and ambiguity, are dependent on the particular circumstances, and require discussion with outside experts. Lay people in France appear, in general, to think more in accordance with American and British than with French laws, legal decisions, and medical ethical dictums.

Our second major finding was that lay participants could be separated into quite distinct groups. A minority (9\%) was opposed to breaking confidentiality to protect a spouse in all cases under consideration. Another minority (12\%) was in favor of it in all cases. The lay people in the current study, therefore, were polarized about this issue, just as people in France are polarized about other controversial issues of medical ethics, such as the acceptability of ending the life of a suffering patient (Teisseyre et al., 2005) or teenagers' abortion (Muñoz Sastre et al., 2007). Some of the lay participants (17\%) were influenced only by whether or not the psychiatrist sought the advice of an expert; they appeared to think that the issue was so morally ambiguous that the psychiatrist needed such guidance.

Most of the lay people (62\%) took all factors into account in their judgments, although not always in the same way. A negative attitude toward appropriate treatment was associated with a greater degree of acceptance of breaking confidentiality for almost two-thirds of this majority group, but with a lesser degree of acceptability for the others. The latter participants, whose overall judgments of acceptability were higher than those of the former, may have considered that if the patient was really willing to consider treatment, he would be led to inform his spouse about his intention to follow a therapy, and as a result, informing the spouse would, for the psychiatrist, no longer involve breaking confidentiality. Future research is, however, needed for better understanding of this difference in the use of the attitude toward therapy factor. 
Overall, these cluster results are consistent with those of Guedj et al. (2006). They found the same pattern of clusters with similar proportions of participants in the different clusters.

Our third major finding was that psychologists differed considerably from lay participants as regards the overall level of acceptability (but not as regards the way the information was used). Lay people considered breaking confidentiality as moderately acceptable (a mean rating of 12.97 on a $22-\mathrm{cm}$ scale) even though some of them, or their family members, were likely to have suffered from mental health troubles and to want this information to remain private. Psychologists rated breaking confidentiality as far less acceptable (a mean rating of 7.97).

Why were psychologists so different? We can offer a few speculations. First, they, like psychiatrists, deal routinely in their practices with very sensitive information about their patients and are more aware than most lay people of the importance of confidentiality. Second, psychologists in France, as well as in the United States and the United Kingdom, are repeatedly taught about the importance of confidentiality. Third, since the scenarios were specifically about mental health patients, the psychologist participants were able to imagine themselves in such a decision-making situation, while the lay people had to imagine others. Fourth, even in France, with fewer malpractice suits than in the U.S., psychologists may be more sensitive than lay participants to the threat of lawsuits, and they may deal with this threat by focusing more on the single guiding principle of confidentiality.

It is surprising, therefore, that the medical doctors' mean acceptability rating (13.09) was high even though they would be expected to be at least as sensitive as psychologists to the importance of patient confidentiality and the threat of lawsuits. Furthermore, in the study of Guedj et al. (2006), the physician participants were strongly opposed to breaching confidentiality. It is dangerous to draw conclusions from such small samples of medical doctors (10 in this study, 7 in Guedj et al., 2006). Nonetheless, differences may have resulted from the quite different scenarios in Guedj's study: the decision makers were physicians (not psychiatrists), the threat was a disease (not violence), and the worst case (implied, not named) was HIV infection. Medical doctors are well aware that special protection has been accorded to HIV victims, but not to potential spouse abusers, to protect them from the consequences of unwanted revelation of their condition.

The intermediate position taken by the nursing personnel (mean acceptability rating of 9.83) may reflect their intimate involvement in both the medical and psychological concerns of their patients.

Our study has several limitations. First, the participants were a convenience sample of people in region of Toulouse, France. The sample was not representative of the French public in gender, age, or educational level, although it is reassuring that gender, age and educational level had no effect on acceptability judgments and were not involved in any interaction. Everyone in the sample grew up in a Christian tradition, but only 5\% were regular churchgoers; and none were Jews or Moslems, whose views on confidentiality might be quite different (Mendelson, 1998; Padela, 2007). The results may not, therefore, be fully generalizable to the French public (particularly to France's growing Islamic population), much less to people in other countries. Second, the samples of nursing personnel, medical doctors, and psychologists were small in size. The study findings need to be confirmed, therefore, on other samples of health professionals as well as of the public. Third, the ratings were made about hypothetical scenarios, rather than real cases. Fourth, multiple other factors influence, of course, the decisions of individual psychiatrists and patients, even though, as stated in the Introduction, previous work suggested that the factors we studied have wide generalizability.

In spite of these limitations, our findings, added to those of Guedj et al. (2006), should demonstrate to psychiatrists, other health professionals, policy makers, lawyers, and others that situational factors are likely to influence the majority of lay people's judgments of the acceptability of the decision by a psychiatrist or other health professional to break patient confidentiality.

\section{Appendix A. Examples of scenarios}

\section{\# 1}

Mr. Marcelin comes to see psychiatrist Dr. Calvet. During the appointment, Mr. Marcelin declares bluntly that he intends to kill his wife. Dr. Calvet takes Mr. Marcelin's threat very seriously because in his mind the diagnosis of mental illness is not in doubt.

Dr. Calvet devotes considerable time to talking with Mr. Marcelin about the consequences of this act, its gravity and its repercussions for Mr. Marcelin's future life. Following this discussion, Mr. Marcelin is considering undergoing appropriate psychotherapy.

Concerned nonetheless for Mrs. Marcelin's life, Dr. Calvet decides to call her and inform her of her husband's intentions and the risks entailed. Before taking this step, Dr. Calvet takes the precaution of asking the advice of Professor Sudre, a specialist in this area.

To what degree do you think that the decision made by Dr. Calvet is acceptable?

Not at all acceptable 0-0-0-0-0-0-0-0-0-0-0-0-0-0-0-0-0-0-0-0-0-0-0 Completely acceptable.

\section{French original}

Monsieur Marcelin est venu consulter le Docteur Calvet, psychiatre. Au cours de la consultation, Monsieur Marcelin déclare froidement son intention de tuer son épouse. Le Docteur Calvet prend très au sérieux la menace de Monsieur Marcelin car pour celui-ci, le diagnostic de maladie mentale ne fait de doute.

Le Docteur Calvet a consacré beaucoup de temps à discuter avec Monsieur Marcelin des conséquences de cet acte, de sa gravité et de ses répercutions sur la vie future de Monsieur Marcelin. Suite à cette discussion, Monsieur Marcelin envisage de suivre un traitement psychothérapeutique approprié.

Inquiet néanmoins pour la vie de Madame Marcelin, le Docteur Calvet a décidé d'appeler celle-ci et de la tenir informée de l'intention de son mari et des risques encourus. Avant de faire cette démarche, le Docteur Calvet a pris la précaution de demander l'avis du Professeur Sudre, spécialiste du domaine.

Dans quelle mesure pensez-vous que la décision prise par le Docteur Calvet est acceptable?

Pas du tout acceptable 0-0-0-0-0-0-0-0-0-0-0-0-0-0-0-0-0-0-0-0-0-0 Tout à fait acceptable.

\#2

Mr. Marengo comes to see psychiatrist Dr. Cassagne. During the appointment, Mr. Marengo declares bluntly that he intends to beat his wife severely. Dr. Cassagne takes Mr. Marengo's threat into account, but to Dr. Cassagne the diagnosis of mental illness is not at all certain.

Dr. Cassagne discusses only briefly with Mr. Marengo the consequences of this act, its gravity and its repercussions for Mr. Marengo's future life. Following this discussion, Mr. Marengo refuses to undergo appropriate psychotherapy.

Concerned nonetheless for Mrs. Marengo's life, Dr. Cassagne decides to call her and inform her of her husband's intention and the risks entailed. This decision Dr. Cassagne makes on his own.

To what degree do you think that the decision made by Dr. Cassagne is acceptable?

Not at all acceptable 0-0-0-0-0-0-0-0-0-0-0-0-0-0-0-0-0-0-0-0-0-0-0 Completely acceptable.

\section{French original}

Monsieur Marengo est venu consulter le Docteur Cassagne, psychiatre. Au cours de la consultation, Monsieur Marengo déclare froidement son intention de battre violemment son épouse. Le Docteur Cassagne prend en compte la menace de Monsieur Marengo, mais pour 
le Docteur Cassagne le diagnostic de maladie mentale n'est pas du tout certain.

Le Docteur Cassagne n'a évoqué que brièvement avec Monsieur Marengo les conséquences de cet acte, de sa gravité et de ses répercutions sur la vie future de Monsieur Marengo. Suite à cette discussion, Monsieur Marengo refuse de suivre un traitement psychothérapeutique approprié.

Inquiet néanmoins pour la vie de Madame Marengo, le Docteur Cassagne a décidé d'appeler celle-ci et de la tenir informée de l'intention de son mari et des risques encourus. C'est une décision que le Docteur Cassagne a pris seul.

Dans quelle mesure pensez-vous que la décision prise par le Docteur Cassagne est acceptable?

Pas du tout acceptable 0-0-0-0-0-0-0-0-0-0-0-0-0-0-0-0-0-0-0-0-0-0 Tout à fait acceptable.

\section{References}

American Medical Association. (1994). AMA code of medical ethics. E-5.05 Confidentiality. Issued December 1983; updated June 1994. Available at $h t t p: / / w w w . a m a-a s s n$. org/ama/pub/category/2498.htm, accessed 19 February 2005.

Anderson, N. H. (1981). Foundation of information integration theory. San Diego, CA Academic Press.

Anderson, N. H. (1982). Methods of information integration theory. New York: Academic Press. Anderson, N. H. (1996). A functional theory of cognition. Hillsdale, NJ: Erlbaum Associates. Bailey, B. (1999). National Report on the situation of gendered violence against women and girls. Jamaica: UNDP.

British Medical Association (1999). Confidentiality \& disclosure of health information. Available at $h t t p: / / w w w . b m a . o r g . u k$, accessed 30 January 2005

Chenneville, T. (2000). HIV, confidentiality and duty to protect: A decision-making model. Professional Psychology: Research and Practice, 31, 661-670.

Code pénal. Available at www.legifrance.gouv.fr, accessed 25 November 2006

Code de santé publique. Available at www.legifrance.gouv.fr, accessed 25 November 2006.

Conseil national de l'Ordre des Médecins (1996). Code de déontologie médicale.Paris: Editions du Seuil Commentary by L René.

Daly, M., \& Wilson, M. I. (1994). The evolutionary psychology of male violence. In J. Archer (Ed.), Male violence (pp. 253-288). London: Routledge Kegan Paul.

de Vries Robbe, M., March, L., Vinen, J., Horner, D., \& Roberts, G. (1996). The prevalence of domestic violence among patients attending a hospital emergency department. Australian and New Zealand Journal of Public Health, 20, 364-368.

Erickson, S. H. (1990). Counseling the irresponsible AIDS client: Guidelines for decision making. Journal of Counseling and Development, 68, 454-455.

Erickson, S. H. (1993). Ethics and confidentiality in AIDS counseling: A professional dilemma. Journal of Mental Health Counseling, 15, 118-131.

Felthous, A. R. (1999). The clinician's duty to protect third parties. Psychiatry Clinics of North America, 22, 49-60.

General Medical Council (2004). Confidentiality: protecting and providing information. Available at http://www.gmc-uk.org/standards/secret.htm, accessed 30 January 2005.
Guedj, M., Muñoz Sastre, M. T., Mullet, E., \& Sorum, P. C. (2006). Under what conditions is the breaking of confidentiality acceptable to lay people and health professionals? Journal of Medical Ethics, 32, 414-419.

Hoerni, B., \& Benezech, M. (1996). Le secret médical: Confidentialité et discrétion en médecine. Paris: Masson.

Hook, M. K., \& Cleveland, J. L. (1999). To tell or not to tell: Breaching confidentiality with clients with HIV and AIDS. Ethics and Behavior, 9, 365-381.

Jaspard, M.and the "Enquête Nationale sur les Violence Envers les Femmes en France" (ENVEFF) team. (2001). Nommer et compter les violences envers les femmes: une première enquête nationale en France Paris: INED.

Jones, C. (2003). The utilitarian argument for medical confidentiality: A pilot study of patients' views. Journal of Medical Ethics, 29, 348-352.

Mazza, D., Lawrence, J. M., Roberts, G. L., \& Knowlden, S. M. (2000). What can we do about domestic violence? Medical Journal of Australia, 173, 532-535.

McGuire, J., Nieri, D., Abbott, D., Sheridan, K., \& Fisher, R. (1995). Do Tarasoff principles apply in AIDS-related psychotherapy? Ethical decision making and the role of therapist homophobia and perceived client dangerousness. Professional Psychology, 26, 608-611.

Memeteau, G. (1995). Le rapport de la commission René sur le secret professionnel. Douze propositions en vue d'améliorer les pratiques. Médecine et Droit, 10, 8-10.

Mendelson, D. (1998). Medical duty of confidentiality in the Hippocratic tradition and Jewish medical ethics. Journal of Law and Medicine, 5, 227-238.

Moatti,J. P., Souville, M., Obadia, Y., Morina, M., Sebbah, R., Gamby, T., Gallais, H., \& Gastault, J. A. (1995). Ethical dilemma in care for HIV infection among French general practitioners. Health Policy, 31, 197-210.

Mouzos, J. (1999). New statistics highlight high homicide rate of indigenous women. Indigenous Law Bulletin, 4, 16-17.

Muñoz Sastre, M. T., Pecarisi, C., Legrain, E., Mullet, E., \& Sorum, P. C. (2007). Acceptability in France of induced abortion for adolescents. American Journal of Bioethics, 7, 26-32.

Offit, K., Groeger, E., Turner, S., Wadsworth, E. A., \& Weiser, M. A. (2004). The "duty to warn" a patient's family members about hereditary disease risks. JAMA, 292, 1469-1473.

Padela, A. I. (2007). Islamic medical ethics: A primer. Bioethics, 19, 169-178.

Regan, J. J., Alderson, A., \& Regan, W. M. (2002). Health care providers' duty to warn. Southern Medical Journal, 95, 1396-1399.

Roberts, G., Williams, G., Lawrence, J., \& Raphael, B. (1998). How does domestic violence affect women's mental health? Women and Health, 28, 7-34.

Rodríguez, M. A., McLoughlin, E., Nah, G., \& Campbell, J. C. (2001). Mandatory reporting of domestic violence injuries to the police: What do emergency department patients think? JAMA, 286, 580-583.

Rubanowitz, D. E. (1987). Public attitudes toward psychotherapist-client confidentiality. Professional Psychology, 18, 613-618.

Scarano, V. R., Baily, C. M., \& Banfield, J. R. (2002). The Texas Supreme Court speaks: Mental health professionals have no duty to warn or protect third parties. Texas Medicine, 98, 61-64.

Stewart, T. M., \& Reppuci, N. D. (1994). AIDS and murder: Decisions regarding maintenance of confidentiality versus the duty to protect. Law and Human Behavior, 18, 107-120.

Teisseyre, N., Mullet, E., \& Sorum, P. C. (2005). Under what conditions is euthanasia acceptable to lay people and heath professionals? Social Sciences and Medicine, 60 357-368.

Totten, G., Lam, D. H., \& Reeder, G. D. (1990). Tarasoff and confidentiality in AIDS-related psychotherapy. Professional Psychology, 21, 155-160. 